A.A. Baranov ${ }^{1,2}$, V.Yu. Al'bitskii ${ }^{1}$, S.A. Sher ${ }^{1}$

${ }^{1}$ Scientific Center of Children's Health, Moscow, Russian Federation

${ }^{2}$ Sechenov First Moscow State Medical University, Russian Federation

${ }^{3}$ Pirogov Russian National Research Medical University

\title{
Pediatric mortality at the Moscow Imperial Orphanage: reality and myths
}

\section{Author affiliation:}

Sher Stella Abel'evna, PhD, senior research scientist at the department of social pediatrics of the Scientific Center of Children's Health (Federal State Budgetary Institution)

Address: bld. 1, 2, Lomonosovskii Ave., Moscow, 119991, tel.: +7 (915) 438-6914;

e-mail: anastel@mail.ru , embryotox@,nczd.ru

Article received: 27.02.2014. Accepted for publication: 14.05.2014.

The article is dedicated to the issue of pediatric mortality at the Moscow Imperial Orphanage founded on September 1, 1763, by decree of Empress Catherine II. The authors present results of an analysis of medical statistical data and give an objective assessment of the medical service provided by the Moscow Orphanage in order to understand the positive or the negative role of the Orphanage in the preservation of children's lives. The stated data do not confirm a myth of the Orphanage being a "factory of angels". Despite high pediatric mortality observed in the active period of the Moscow Imperial Orphanage, the doctors succeeded in saving hundreds of thousands of the children left for dead. The care of poor infants and preservation of their lives played an important role in the development of medical care and social welfare of the pediatric population of Russia.

Keywords: Moscow Imperial Orphanage, infant mortality, "factory of angels", preservation of children's lives.

In the middle of the XVIII century the lack of population for development and invasion of vast territories of Russia became apparent. Population decline was largely determined by high infant mortality rate; that issue was brought into consideration of the statesmen by M.V. Lomonosov who proposed a number of measures for protection of infants and waged the battle to reduce neonatal morbidity and mortality. The issues of infant life preservation were also considered by an outstanding statesman I.I. Betsky who had suggested the project of an Orphanage. On September 1, 1763, Empress Catherine II signed the Manifesto on the Establishment of the Orphanage with a Hospital for the Preservation of Lives of the Neonates Born in Poverty and to Poor Mothers in Moscow. It went down in history as the Moscow Imperial Orphanage and was declared a state institution. The establishment had the following mission: "to save lives, improve health and form righteous souls, for one never goes without the other" ${ }^{1}$.

Reliable information on the infant mortality rate in Russia appeared only in the second half of the nineteenth century. According to academician K. Hermann, only 555 out of 1,000 newborn boys would reach the age of six [1]. V. Snegirev (1867) observed that infants constituted 31.4\% of all the deaths in Russia in 1859-1866 [2].

In the late XIX - early XX centuries, Russia consistently ranked first among the European countries in terms of infant mortality. According to P.I. Kurkin, who studied infant mortality in the European part of Russia in 1867-1911, the average infant mortality rate was $26-27 \%$; it would not fall below $23-24 \%$ in the best of years and would exceed $30 \%$ in the worst [3].

In 1907-1911, the infant mortality rate in Russia was twice as high as in England and thrice as high as in Sweden or Norway [4].

\footnotetext{
${ }^{1}$ General plan of the Imperial Orphanage and the Hospital for Poor Mothers in Moscow (1763-1767). Saint Petersburg, 1889. p. XXII.
} 
As a result, the issue of infant mortality could not have been ignored neither by the medical community nor by governmental authorities.

The Decree to the Ruling Senate of Russia as of May 31, 1913, stated that "high infant mortality and morbidity rate observed in the Empire, especially in the neonates, negatively affects the State, quantitatively reduces the population and weakens its physical qualities" [5].

Analyzing the reasons of the enormous infant mortality in Russia, famous pediatrician N.P. Gundobin (1906) wrote: "The three most common diseases, namely, measles, scarlet fever and diphtheria cause death of more than 2,000 children only in Saint Petersburg" ${ }^{2}$. He also noted that apart from the poor sanitary state of the city and the ignorance of the population "the cause of the high infant mortality rate in the major centers lies in congestion, overcrowding and lack of concern about the arrangement of apartments for the poor class". Children died at overcrowded hospitals from further spread of infection, which is why the Saint Petersburg hospital was often called "the factory of angels" in press [6].

A particularly high infant mortality rate was observed at Orphanages. This undeniable fact attracted attention of both contemporaries and those subsequent historians, who have studied the problem of infant health in Imperial Russia. There is still no virtually articulate, science-based conception of the real state of infant mortality at the institutions established to preserve lives of children.

What were the reasons for the high mortality rate among the nursed children of the Moscow Orphanage? Analyzing the main causes of infant mortality, one should primarily note the antenatal factor (in modern parlance). The neonates adopted to the Orphanage were "of a weak, scrofulous, exhausted constitution and did not possess vital force". Such a population of children represented a high risk group in terms of infant morbidity and mortality. The situation was aggravated by "the lack of moral composure, fear and other circumstances which occurred during the process of conception; sometimes - by violence, internal agony, effect of a hidden passion and, finally, the process of giving birth in a poor social stratum without any doctoral care in itself..." ${ }^{3}$.

The second important reason of the high morbidity and mortality of infants was the lack of wet nurses and, therefore, the transition to bottle feeding, negative role whereof is well-known. That problem was first encountered as early as in 1764 (in the first year of adopting children to the Orphanage): there were only 35 wet nurses for 523 infants. County doctor N.F. Mikhaylov pointed out the fact that "there is an almost constant and tangible lack of wet nurses in general and in particular with good milk." Children were chronically hungry because "no bonuses and benefits can attract the proper amount of wet nurses to the Orphanage in the summer period" [7]. The deficit of wet nurses (in varying degrees) has accompanied the activities of the Moscow Orphanage throughout its history.

The third pivotal cause leading to high infant morbidity and mortality rate resulted from enormous congestion of nursed children. Initially, it was assumed that the Orphanage could adopt 500 children, but in reality Orphanages of St. Petersburg and Moscow "hosted two or even three times more children than the established hygienic norms" ${ }^{4}$. Over 1,500 babies with wet nurses, nurses and other servants stayed infant care units. These units departments could fit only up to 900 neonates (more or less satisfactorily); accommodation of more children would entail increase in morbidity and mortality. The aforementioned factors contributed to the rapid infection contamination of infants with measles, diphtheria, scarlet fever and other common pediatric infections. The lack of proper knowledge of etiology, pathogenesis, treatment and prevention of infectious diseases in the mentioned period of time ought not to be ignored as well. One of the causes of ill-being of nursed children was the lack of individual care given to neonates at the Orphanage.

\footnotetext{
${ }^{2}$ N.P. Gundobin. Pediatric mortality in Russia and control measures. Saint Petersburg, 1906. p. 14.

${ }^{3}$ History of Orphanages in Saint Petersburg and Moscow. Readings at the Imperial Society of History Russian Antiquities at the Moscow University. Volume 2. P. 141-142.

${ }^{4}$ N.P. Gundobin. Pediatric mortality in Russia and control measures. Saint Petersburg, 1906. 31 p.
} 
An important reason, which affected infant mortality rate extremely negatively, was the so called "nursed children business".

Architecture of the buildings themselves should also be mentioned among the secondary causes contributing to the persistently high mortality rate among nursed children: massive, multistoried buildings with a narrow central corridor and not entirely satisfactory sanitary condition of the surrounding area. Terrain features (the Orphanage was built in the lowland, where the sewage-saturated ground waters of the river Yauza would drain) and a contaminated area of Moscow located nearby (Myasnitskaya Street with Khitrov market and Yauzsky Boulevard with night shelters were among the dirtiest places in the city) were making matters worse; all of these facts contributed to the increased pediatric morbidity and mortality rate $[8,9]$.

Pre-revolutionary authors also frequently mentioned "harsh Russian climate" among the reasons contributing to the increased infant morbidity and mortality. In the event of severe winter frosts, "the infants on delivery to the Orphanage or, vice versa, transported to the village for further feeding would be completely frost-bitten; they would catch a cold and die in a few days" [10].

The most significant and outrageous levels of infant mortality were observed in the first years after establishment of the Orphanage (when it was still being built and finding its feet), as well as in the extreme periods of time - during epidemics, wars and famines.

In 1764, when the foundation laying of the first building of the Orphanage was only just completed, infants were being adopted to the foster home in the building in Solyanka fit for temporary adoption of illegitimate children. 424 out of the 523 adopted infants died, i.e. the mortality rate was $81.1 \%$ [11]. This high rate was one of the main factors of establishment of the myth that imperial orphanages were "factories of angels", "killing chambers" (for the authors from pre-revolutionary Russia), and institutions of the "cynical" bourgeois charity (for Soviet historians). However, this is not consistent with reality.

Two conflicting opinions on orphanages coexisted in the mentioned period of time. From our point of view, this situation was very accurately described by M. Sokolovskiy. Some authors "had rather biased views and spoke of orphanages in Russia in a very unflattering manner... others - in an extremely enthusiastic way. “...” Extreme measures are not quite just; they scent of that straightforwardness of view, which must not be applied to public issues. "..." Orphanage activity undoubtedly had its dark sides, which were determined by the mere difficulty of orphanage functions, and bright sides, which compensated for the disadvantages of the aforementioned institutions over and above" [12]. Confirmation of the rightfulness of these words can be seen in the number of positive, negative and critical articles on the Moscow Orphanage published in different years.

This article was aimed at attempting to analyze medical and statistical data, provide an objective assessment of the medical service of the Moscow Orphanage and understand the role (positive or negative) of the Hospital in preservation of lives of infants.

As it is mentioned below, the real situation is not consistent with the opinions of certain county doctors and medical historians that Moscow and Saint Petersburg orphanages proved unequal to the task of preservation of lives of infants assigned to them. These accusations were often clearly paid-for and ideological. The following vivid example confirms this assertion. The book by E.M. Conyus "Paths of development of protection of maternity and infancy in the Soviet Union (1917-1940)" provides data on the mortality rate of infants at the Moscow orphanage in 1907 $40 \%$. Nonetheless, the author argues that, in fact, the mortality rate of the Orphanage inmates was 2 times higher and quotes data from the publication by the chief doctor of the Moscow Orphanage N.F. Miller (mortality rate reached up to $81 \%$ ) to confirm her assertion, forgetting to point out that these data covered the XVIII century, when Moscow was affected by a raging epidemic of smallpox and the Orphanage buildings had still been being built [13].

Moreover, E.M. Conyus claims that many researchers had challenged the official data on mortality rate at orphanages. She refers to county doctors Mikhaylov, Zachek and Radulevich, who, according to her, insisted in their reports at Pirogov conferences that the mortality rate at the Moscow Orphanages could reach up to $80 \%$, i.e. exceeded the official rate twice. 
We found the work by N.F. Mikhaylov and observed some discrepancy in the data presented by E.M. Conyus. According to N.F. Mikhaylov who worked in the Ruza district of the Moscow Governorate, the mortality rate at the Moscow orphanage in 1877-1879 was 40\%. However, an extremely high mortality rate $(88 \%)$ was observed in children with prenatal syphilis $(3.5 \%$ of all the inmates) [7].

Our study of medical records of the Moscow Orphanage for the same period of time (1877-1879) showed that in 1877 the mortality rate was $20.8 \%$, in $1878-23.4 \%$, in $1879-28.6 \%$ [14]. We would like to note that the data presented by N.F. Mikhaylov do not also absolutely accurately reflect the mortality rates among nursed children in the specified time period.

Another author, I.M. Radetskiy (1894), confirms certain critical reviews on the activity of orphanages and quotes data on infant mortality rates, which were genuinely horrifying in the first years of functioning of the aforementioned institutions; however, he does not indicate that this was the period of a smallpox epidemic. The author emphasized that 116,505 neonates died in the period of 100 years from the opening of the Moscow Orphanage. However, it ought to be mentioned that 468,987 infants were adopted by the institution over the mentioned years, i.e. the mortality rate is $24.8 \%$, that is, within the average infant mortality rate in Russia.

I.M. Radetskiy also pointed out that the infant mortality rate at the Moscow orphanage reached $60 \%$ in the summer of 1888 [15]. However, summer leaps of infant mortality were well-known in Russia, especially in rural areas, where the majority of peasant women had to wean babies in the period of fieldwork (A.A. Baranov, V.Y. Albitskiy, 2009) [2].

Analysis of the medical report of the Moscow Orphanage for 1888 demonstrated that the mortality rate in the mentioned year rose up to $43.17 \%$ due to both "the significant increase in the number of infants brought to the Orphanage, persistent overcrowding of wards" and an enormous lack of wet nurses (far worse than in previous years). Out of all the adopted infants, "1/4 were sick, extremely weak and premature on adoption" and "had all the indications of a quick death, because they were inviable or suffered from syphilis." Summer months were characterized by the worst overcrowding, as rural wet nurses would not take nursed children because of their involvement in the fieldwork; early introduction of supplementary feeding often caused development of severe enteritis with fatal outcomes.

Doctor N.N. Ginzburg (1904), who studied the issues of infant care in Russia, claimed that out of the 40,600 infants adopted over 33 years only 4,711 had stayed by 1797 (11\%); the remaining $89 \%$ of the children died or went missing [16]. Similar data were presented by foreign authors J. Russell and R. Cohn (2012), who quote data on the extremely high infant mortality: during the reign of Catherine II (1764-1797), 35,309 (or 87\%) out of the 40,996 infants adopted to the Orphanage died. [17]

According to our calculations based on the data from medical reports of the Moscow Orphanage, "Materials on the history of the Moscow Imperial Orphanage", historical essay on the Orphanage by V. Krasuskiy, as well as statistical data of doctor V.I. Lebedev, who published the results of his research in the "Moscow City Duma Bulletin" in 1896, these infant mortality rates have nothing to do with the reality. From 1764 to 1797, the Orphanage adopted 41,123 infants, 12,307 of whom died (29.9\%); 28,816 survived (70.1\%).

Thus, the authors are not entirely correct to assert a generally high rate of infant mortality, and, it appears, quote data on the mortality rate of preterm infants and syphilitic infants without referring to specific medical and statistical data, repeating the myth of extreme mortality rate at the Moscow Orphanages. The true picture of infant mortality rate at the Moscow Imperial orphanages was as follows:

As early as in 1771-1773, when Moscow was affected by the raging plague and nursed children were accommodated in the first buildings of the Orphanage, no child died of plague. Infant mortality rate in that period was $40-45 \%$. Ten years after the opening of the Orphanage, in 1774 , the mortality rate went down to $24.5 \%$. During the Patriotic War of 1812 , the infant mortality rates rose up to $54.2 \%$ and remained high until 1821, when it went back down to $25.7 \%$ [18, 19$]$. 
According to the chief doctor of the Moscow Orphanage A.I. Blumenthal, infant mortality rate ranged from 19.3 to $22.8 \%$ in the period of $1829-1856$.

In 1857 an increase up to $32.1 \%$ in the mortality rate was observed at the Moscow Orphanage. A.I. Blumenthal explained high mortality with the "deathly" lack of wet nurses in that year - 499 . This meant that "998 children suffered the consequences of the lack of feeding." Thoughtful and dissective, doctor A.I. Blumenthal mentioned significant fluctuations in the infant mortality rate at the Moscow Orphanage, therefore, these figures cannot be judged by one specific year or month. According to his analysis, the mortality rate of children at the Moscow Imperial Orphanage was only $6-8 \%$ higher than the average legitimate infant mortality rate in Moscow [20].

The aforementioned figures do not contradict results of our analysis given in tb. 1, which shows that the infant mortality rate at the Moscow Orphanage was only 5-8\% higher than the average infant mortality rate in Russia in the second half of the XIX century.

Tracing the dynamics of mortality rate among nursed children at the Moscow Orphanage from its foundation until 1914, we clearly see the downward trend despite sporadic leaps in the unfavorable periods (pic.).

Results of our studies have demonstrated that the Moscow Imperial Orphanage adopted over $1,000,000$ children and saved lives of nearly 800,000 children $(71.9 \%)$ in the mentioned period of 150 years of operation (1764-1914; no medical records for 1915-1917) (tb. 2).

Another major problem that the doctors of the Orphanage encountered was high infant mortality rate among nursed children in rural areas; however, this is a topic for another study.

Thus, the quoted data do not conform to the myth that Moscow and Saint Petersburg orphanages were "factories of angels." This term was only emotionally used by pre-revolutionary authors and ideologically - by Soviet authors.

Despite the problem of high infant mortality rate throughout the period of operation of the Moscow Imperial Orphanage, doctors and personnel there managed to save lives of hundreds of thousands of the infants doomed to death. Therefore, the opinion of inability and ineffectiveness of the Moscow Orphanage should be deemed erroneous. Despite downsides of its operation, criticism for high infant mortality rate, lack of family-like concern for infant care and "nursed children business" in rural areas, we should admit that care of poor infants and preservation of their lives played an enormous role in the development of health care and social security of infant population in Russia.

\section{REFERENCES}

1. Al'bitskii V. Yu. Infant mortality in Russia before the Revolution. Nizhegorodskii meditsinskii zhurnal - Nizhniy Novgorod medical journal. 1994; 3:131-135.

2. Baranov A. A., Al'bitskii V. Yu. Smertnost' detskogo naseleniya Rossii (tendentsii, prichiny $i$ puti snizheniya). Vyp. 3 [Pediatric Mortality in Russia (Tendencies, Causes and Methods of Reduction). Edition 3]. Moscow, Union of Pediatricians of Russia, 2009. pp. 53-54.

3. Kurkin P.I. Smertnost' grudnykh detei [Infant Mortality]. Moscow, People's Commissariat for Health Press, 1925. 60 p.

4. Antonov A.N. Smertnost' grudnykh i malykh detei, ee prichiny i mery bor'by [Mortality of Infants and Small Children: Causes of Methods of Reduction]. Leningrad-Moscow, State Medical Press, 1931. 255 p.

5. Ustinov A.N. The first idea of protecting neonates (Historical reference). Protection of maternity and infancy. Petrograd: Izdanie Vserossiiskogo Popechitel'stva ob okhrane materinstva i mladenchestva - Petrograd: Periodical of the All-Russian Patronage of Maternity and Infancy. 1916; 3: 22-27.

6. Gundobin N.P. Detskaya smertnost' v Rossii i mery bor'by s neyu [Pediatric Mortality in Russia and Control Measures]. St. Petersburg, 1906. 31 p. 
7. Mikhailov N.F. Obshchaya kharakteristika deyatel'nosti nashikh vospitatel'nykh domov [Overall Performance of Russian Orphanages]. Moscow, S.P. Yakovlev Publishing Partnership, 1887. $21 \mathrm{p}$.

8. Moscow Orphanage at the present day. Vestnik blagotvoritel'nosti - Charity Bulletin. 1898; 12: 66-77.

9. Skvortsov I.P. On pediatric morbidity and mortality at the Moscow Imperial Orphanage. Sbornik sochinenii po sudebnoi meditsine, sudebnoi psikhiatrii, meditsinskoi politsii, obshchestvennoi gigiene, epidemiologii, meditsinskoi geografii $i$ meditsinskoi statistike, izdavaemyi Meditsinskim departamentom - Collected works on forensic medicine, forensic pathology, medical police, public hygiene, epidemiology, medical geography and medical statistics published by the Medical Department. 1876; 2: 135-147.

10. Istoriya Vospitatel'nykh domov v Peterburge i Moskve. V kn.: «Chteniya v Imperatorskom obshchestve istorii i drevnostei rossiiskikh pri Moskovskom universitete». Kn. 2 [History of Orphanages in Saint Petersburg and Moscow. From book "Readings at the Imperial Society of History Russian Antiquities at the Moscow University". Volume 2]. Moscow, University Press, 1860. pp. 93-160.

11. Materialy dlya istorii Imperatorskogo Moskovskogo vospitatel'nogo doma. Vypusk 1 (3) [Materials on the History of the Moscow Imperial Orphanage. Edition 1 (3)]. Moscow, Moscow Military District Headquarters Press, 1914. 261 p.

12. Sokolovskii M. Catherine the Great as a benefactress (Historical-economical essay). Saint Petersburg: Vestnik blagotvoritel'nosti-Charity Bulletin. 1902; 2: 13-39.

13. Konyus E.M. Puti razvitiya sovetskoi OMM (1917-1940) [Paths of Development of Protection of Maternity and Infancy in the Soviet Union (1917-1940)]. Moscow, 1954. pp. 1314.

14. Otchety po Imperatorskomu Moskovskomu vospitatel'nomu domu za $1879 \mathrm{~g}$ [Reports on the Moscow Imperial Orphanage: 1879]. Moscow, Former Publishing House of A.V. Kudryavtseva, 1880. $41 \mathrm{p}$.

15. Radetskii I.M. Broshennye deti (Materialy $k$ voprosu o podkidyshakh) [Abandoned Children (Materials on the Problem of Foundlings)]. Saint Petersburg, 1894. 53 p.

16. Ginzburg N.N. Prizrenie podkidyshei v Rossii (opyt istoriko-kriticheskoi otsenki). Iz zhurnala "Trudovaya pomoshch'», aprel'-iyun' $1904 \mathrm{~g}$ [Charity for Foundlings in Russia (Experience of Historical-critical Assessment). From Journal "Labor assistance", April-June 1904]. Saint Petersburg, 1904. 83 p.

17. Russell J., Cohn R. Moscow Orphanage. Edinburg, Scotland, United Kingdom, Lennex Corp., 2012. 101 p.

18. Krasuskii V. Kratkii istoricheskii ocherk [Brief Historical Essay]. Moscow, V.Y. Barbey Publishing House, 1878. pp. 239.

19. Al'bitskii V.Yu., Baranov A.A., Sher S.A. Istoriya Nauchnogo tsentra zdorov'ya detei Rossiiskoi akademii meditsinskikh nauk (1763-2013) [History of the Scientific Center of Children's Health of the Russian Academy of Medical Sciences (1763-2013)]. Moscow, Pediatr, 2013. $468 \mathrm{p}$.

20. Blumental' A.I. O smertnosti grudnykh detei v Imperatorskom Moskovskom vospitatel'nom dome (Iz Moskovskoi meditsinskoi gazety № 21-22, 1859) [On Infant Mortality at the Moscow Imperial Orphanage (From the Moscow Medical Paper No. 21-22, 1859)]. Moscow, Katkov \& Co. Publishing House, 1859. 32 p.

Table 1. Infant mortality rate in the Russian Empire and the Moscow Imperial Orphanage

\begin{tabular}{|c|c|c|}
\hline Year & $\begin{array}{c}\text { Russian Empire (per 100 live-born } \\
\text { neonates) }\end{array}$ & $\begin{array}{c}\text { Moscow Orphanage (per 100 adopted } \\
\text { infants) }\end{array}$ \\
\hline
\end{tabular}

\footnotetext{
5 A.A. Baranov, V.YU. AlbitskiI. Pediatric mortality in Russia (tendencies, causes and methods of reduction). Edition 9, series "Social pediatrics". Moscow, Union of Pediatricians of Russia, 2009. p. 55.
} 


\begin{tabular}{|c|c|c|}
\hline Year & $\begin{array}{c}\text { Russian Empire (per 100 live-born } \\
\text { neonates) }^{\mathbf{5}}\end{array}$ & $\begin{array}{c}\text { Moscow Orphanage (per 100 adopted } \\
\text { infants) }^{\mathbf{6}}\end{array}$ \\
\hline 1867 & 24.3 & 30.6 \\
\hline 1868 & 29.9 & 30.2 \\
\hline 1869 & 27.5 & 26.5 \\
\hline 1870 & 24.8 & 26.9 \\
\hline 1871 & 27.4 & 22.5 \\
\hline 1872 & 29.5 & 24.5 \\
\hline 1873 & 262 & 27.2 \\
\hline 1874 & 26.2 & 22.9 \\
\hline 1875 & 26.6 & 28.1 \\
\hline 1876 & 27.8 & 27.9 \\
\hline 1877 & 26.0 & 22.3 \\
\hline$\ldots$ & $\ldots$ & $\ldots$ \\
\hline 1880 & 28.6 & 23.5 \\
\hline 1881 & 25.2 & 22.9 \\
\hline 1882 & 30.1 & 29.0 \\
\hline 1883 & 28.4 & 29.1 \\
\hline 1884 & 25.4 & 28.1 \\
\hline 1885 & 27.0 & 21.0 \\
\hline 1886 & 24.8 & 31.4 \\
\hline 1887 & 25.6 & 37.4 \\
\hline 1888 & 25.0 & 43.2 \\
\hline 1889 & 27.5 & 44.8 \\
\hline
\end{tabular}

Table 2. The number of adopted, died and survived nursed children at the Moscow Orphanage (1764-1914)

\begin{tabular}{|c|c|c|c|c|}
\hline Decades & $\begin{array}{c}\text { Infants } \\
\text { accepted }\end{array}$ & $\begin{array}{c}\text { Infants } \\
\text { died }\end{array}$ & $\begin{array}{c}\text { Mortality rate by decades } \\
\mathbf{( \% )}\end{array}$ & $\begin{array}{c}\text { Infants } \\
\text { survived }\end{array}$ \\
\hline 1774 & 9,457 & 5,217 & 55.2 & 4,240 \\
\hline 1784 & 1,537 & 2,368 & 18.9 & 10,169 \\
\hline 1794 & 13,442 & 2,946 & 21.9 & 10,496 \\
\hline 1804 & 21,074 & 4,887 & 23.2 & 16,186 \\
\hline 1814 & 30,617 & 11,452 & 37.4 & 29,465 \\
\hline 1824 & 39,179 & 15,889 & 40.5 & 23,290 \\
\hline 1834 & 56,877 & 10,305 & 18.1 & 46,572 \\
\hline 1844 & 71,709 & 13,745 & 19.2 & 57,964 \\
\hline 1854 & 90,184 & 22,571 & 25.0 & 67,613 \\
\hline 1864 & 123,484 & 30,308 & 24.5 & 93,176 \\
\hline 1874 & 114,357 & 30,901 & 27.0 & 83,456 \\
\hline 1884 & 132,106 & 34,391 & 25.9 & 97,715 \\
\hline 1894 & 150,482 & 50,490 & 33.5 & 99,992 \\
\hline 1904 & 114,063 & 43,399 & 38.0 & 70,664 \\
\hline 1914 & 121,565 & 41,212 & 34.4 & 80,353 \\
\hline Total: & $1,101,133$ & 320,081 & $?$ & 791,351 \\
\hline
\end{tabular}

\footnotetext{
${ }^{6}$ V. Krasuskiy. Brief historical essay on the Moscow Imperial Orphanage. Moscow, V.Y. Barbey Publishing House, pp. 70-73.
} 
Pic. Dynamics of mortality rates (\%) of the nursed children at the Moscow Orphanage in 17641914.

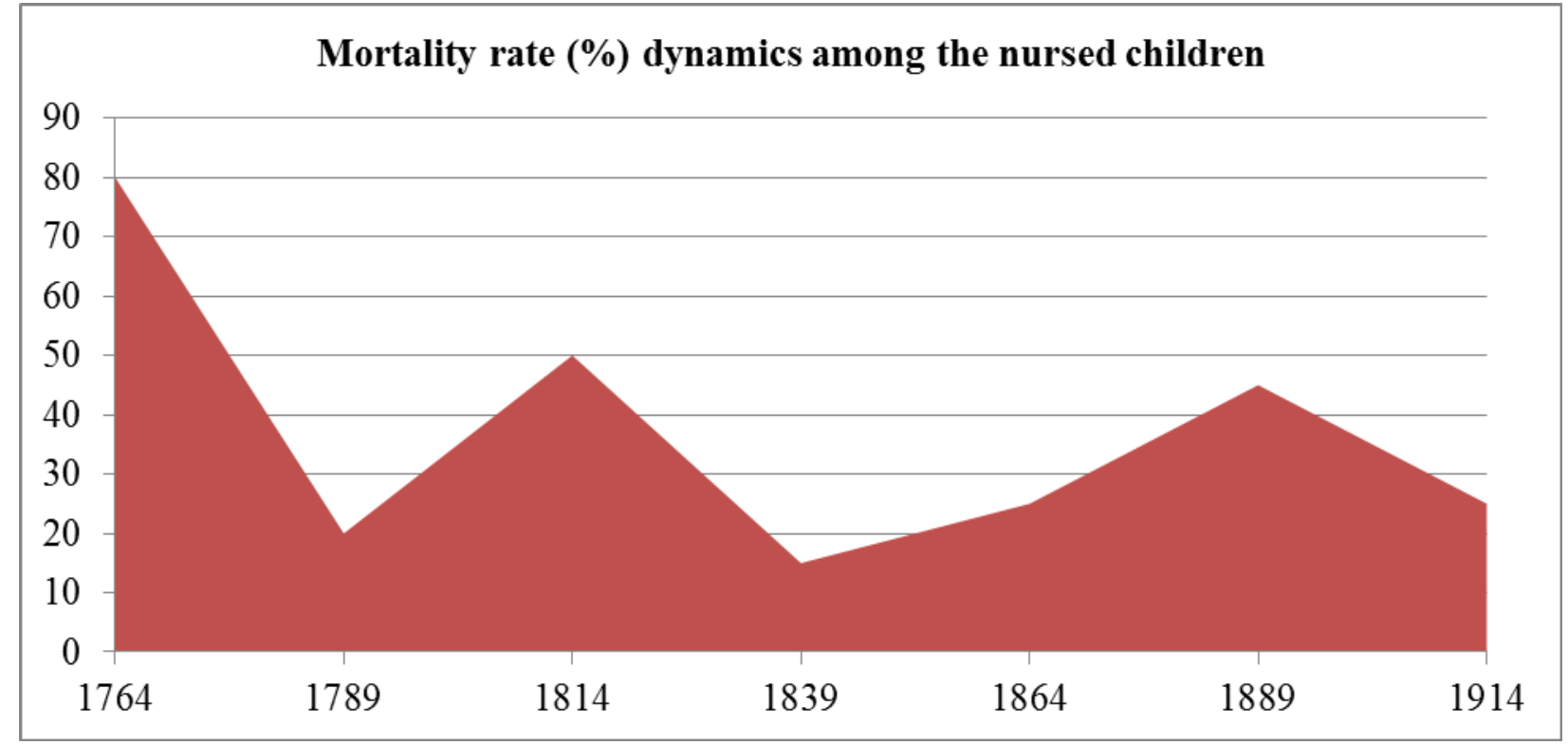

